\title{
FAKTOR-FAKTOR PENYEBAB STRESS KERJA PERAWAT DALAM MERAWAT PASIEN COVID-19
}

\author{
Christina Sudaryanti ${ }^{1}$, Zahra Maulidia ${ }^{2}$ \\ ${ }^{1,2}$ Prodi Ilmu Keperawatan STIKes Yatsi, Tangerang \\ Jl. Aria Santika No. 40A, RT 005/RW011 Margasari, Kec. Karawaci, Kota Tangerang, \\ Banten, Indonesia \\ sudaryantichristina@gmail.com
}

\begin{abstract}
Abstrak
Banyaknya petugas kesehatan yang terpapar Covid-19 menjadi masalah besar bagi staf medis terkhusus perawat yang merawat pasien Covid-19. Tujuan penelitian ini untuk mengetahui faktorfaktor yang berhubungan dengan stress kerja perawat akibat merawat pasien Covid-19 di RS Kanker Dharmais. Desain penelitian ini adalah deskriptif korelasional menggunakan pendekatan cross sectional study. Populasi dalam penelitian ini adalah seluruh perawat yang merawat pasien Covid-19 di RS Kanker Dharmais. Teknik pengambilan sampel random sampling dengan sampel 191 responden. Penelitian dilakukan Juli 2021 - September 2021. Analisis statistik menggunakan Chisquare dengan $\mathrm{p}$-value $(\mathrm{p}<0,05)$. Hasil penelitian menunjukan bahwa mayoritas perawat pasien Covid-19 di RS Kanker Dharmais cenderung mengalami stres kerja pada tingkat berat sebesar $28,8 \%$, sedang 51,3\% dan ringan 19,9\%, usia dewasa muda (26-35 tahun) sebanyak 141 (73.8\%), berjenis kelamin perempuan 140 (73,3\%), sudah menikah 125 (65,4\%), berpendidikan Diploma 106 (55,5\%), masa kerja 1-5 tahun $82(42,9 \%)$, faktor masa kerja ( $p: 0,001)$, faktor hubungan interpersonal ( $p: 0,043$ ) dan faktor beban kerja ( $p: 0,030)$. Disarankan pada perawat selalu menjaga kesehatan dimasa pandemi dan menigkatkan pengetahuan mengenai Covid-19 untuk mengurangi beban stress kerja dalam menangani pasien Covid-19.
\end{abstract}

Kata Kunci : Stress, Ruangan Isolasi dan Covid-19

\section{Abstract}

The number of health workers exposed to Covid-19 is a big problem for medical staff, especially nurses who treat Covid-19 patients. This study aims to determine Factors that cause work stress for nurses in treating Covid-19 patients at Dharmais Cancer Hospital. This type of research is correlational descriptive with cross sectional study approach. The population in this study is all nurses who treat Covid-19 patients at Dharmais Cancer Hospital. Sampling technique random sampling with a sample of 191 respondents. The study was conducted July 2021 - September 2021. Statistical analysis used Chi-square with $p$-value $(p<0.05)$. The results showed that the majority of nurses who treats Covid-19 patients at Dharmais Cancer Hospital tend to experience work stress at a severe level of $28.8 \%$, moderate $51.3 \%$ and mild 19.9\%, young adults (26-35 years) are 141 (73.8\%), female 140 (73.3\% ), married 125 (65.4\%), Diploma 106 (55.5\%), 1-5 years of service 82 (42.9\%), years of service (p:0.001), interpersonal relationship factors ( $p: 0.043$ ) and workload factor ( $p: 0.030$ ). It is recommended that nurses always maintain health during the pandemic and increase knowledge about Covid-19 to reduce the work stress load in dealing with Covid-19 patients.

Keywords : Stress, Isolation Room and Covid-19

\section{PENDAHULUAN}

Covid-19 adalah penyakit yang disebabkan oleh virus corona jenis baru yang pertama kali ditemukan di Wuhan, Cina, yang kemudian oleh WHO dinamakan virus 2019nCov (WHO, 2020). Semenjak pertama kali ditemukan, covid-19 dengan cepat menyebar ke hampir seluruh dunia. Saat ini kasus Covid19 di dunia terkonfirmasi sebanyak 117.332.262 dengan jumlah kematian sebanyak 2.605.356. Di Indonesia kasus covid19 terkonfirmasi sebanyak 1.398 .578 dengan jumlah kematian sebanyak 37.932 , dan angka kesembuhan mencapai 1.216.433. Di RS

Corresponding author:

Christina Sudaryanti

sudaryantichristina@gmail.com 
Kanker Dharmais, sampai akhir tahun 2020 terdapat 380 pegawai yang terkonfirmasi Covid-19 dan menyebabkan 3 orang meninggal.

Masalah terbesar bagi staf medis khususnya perawat yang merawat pasien Covid-19 adalah cenderung lebih berisiko terpapar infeksi karena merawat secara langsung. Hal tersebut berpotensi memicu timbulnya gangguan psikologis berupa stres (Lai et al., 2020). Stres didefinisikan sebagai keadaan tubuh seseorang terhadap situasi dan kondisi yang menimbulkan tekanan, perubahan prilaku, perubahan emosional yang tidak terkontrol, dan lain-lain (Hawari, 2010).

Irza (2016) menyatakan bahwa stres kerja tinggi bisa menyebabkan aktivitas kerja terganggu, produktivitas menurun, kinerja turun dan memicu rendahnya kepuasan kerja, gairah dan semangat menjadi berkurang, komunikasi terhambat, tidak tepat dalam mengambil keputusan, kreatifitas dan inovasi berkurang, serta menurunkan produktifitas kerja.

Donsu (2017) menyatakan bahwa penyebab stress dalam pekerjaan dibagi menjadi dua yaitu : Individual stressor atau berasal dalam diri individu, diantaranya jenis kelamin, umur, status pernikahan, masa kerja, dan lingkungan pekerjaan, sedangkan penyebab stress yang ke dua adalah group stressor antara lain masalah peran, kondisi pekerjaan, hubungan interpersonal, struktur organisasi dan pengembangan karir.

Widyasari (2010) menyatakan peningkatan stres pekerjaan perawat juga bisa dipacu oleh keharusan selalu memberikan pelayanan yang selalu maksimal dalam melakukan asuhan keperawatan. Makin banyak tuntutan dalam suatu pekerjaan maka akan semakin besar juga potensi terjadinya stres kerja Pesant (2016) dalam penelitiannya menyebutkan bahwa perawat dengan beban kerja berlebih bisa mengakibatkan penurunan kesehatan, kualitas pelayanan, motivasi kerja, dan kegagalan tindakan serta meningkatkan potensi terjadinya kelalaian.

Hubungan masa kerja dengan stres kerja berkaitan dengan rasa jenuh dalam bekerja. Pekerja dengan masa kerja lebih lama biasanya memiliki tingkat rasa jenuh terhadap pekerjaan lebih tinggi dibanding pekerja baru. Rasa jenuh tersebut bisa memicu stres di tempat kerja (Munandar, 2011).
Selain beban kerja dan masa kerja, hubungan interpersonal yang kurang baik akibat adanya gangguan dalam interaksi sosial diantara pekerja, atasan, pasien atau keluarga pasien juga berpotensi memicu stres kerja pada perawat (Liliweri, 2015).

Penelitian Laelasari (2016) menunjukkan bahwa tidak terjalinnya hubungan interpersonal yang baik memiliki potensi untuk mengalami stres kerja 9,4 kali lebih besa dibanding dengan adanya hubungan interpersonal yang baik.

Tujuan penelitian ini untuk mengetahui faktor-faktor yang berhubungan dengan stress kerja perawat akibat merawat pasien Covid-19 di RS Kanker Dharmais.

\section{METODE PENELITIAN}

Penelitian ini menggunakan desain penelitian deskriptif korelasional dengan pendekatan cross sectional dimana masa kerja, beban kerja dan hubungan interpesonal yang diduga memiliki hubungan dengan stres kerja perawat diukur dalam satu waktu secara secara bersamaan. Populasi dalam penelitian ini adalah seluruh perawat di RS Kanker Dharmais yang bertugas melakukan asuhan keperawatan pasien Covid-19 yaitu sebanyak 365 perawat. Berdasarkan perhitungan rumus didapatkan jumlah sampel sebanyak 191 responden, diambil menggunakan teknik random sampling. Data dikumpulkan secara langsung dari responden menggunakan alat bantu kuesioner. Analisis statistik menggunakan analisis univariat dan bivariat dengan uji Chi-square.

\section{HASIL DAN PEMBAHASAN}

\section{Hasil Analisis Univariat}

Tabel 1. Masa Kerja Perawat

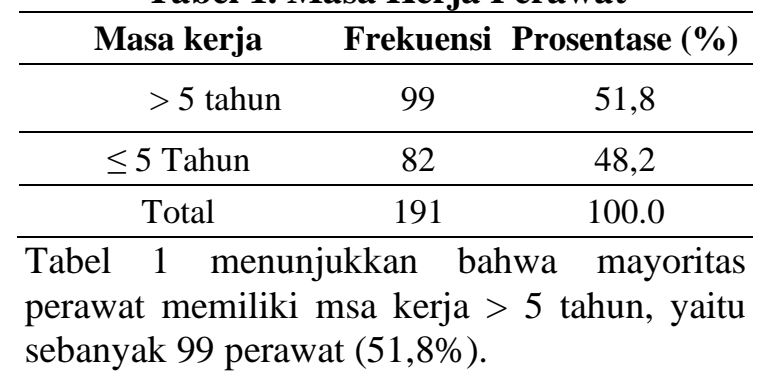


Tabel 2. Gambaran Beban Kerja Perawat

\begin{tabular}{ccc} 
Beban Kerja & Frekuensi & $\begin{array}{c}\text { Prosentase } \\
(\mathbf{\%})\end{array}$ \\
\hline Ringan & 38 & 19,9 \\
\hline Sedang & 98 & 51,3 \\
\hline Berat & 55 & 28,8 \\
\hline Total & 191 & 100.0 \\
\hline
\end{tabular}

Tabel 2 menunjukkan sebagian perawat memiliki beban kerja sedang sebanyak 98 perawat $(51,3 \%)$.

Tabel 3. Gambaran Hubungan Interpersonal Perawat

\begin{tabular}{ccc}
\hline $\begin{array}{c}\text { Hubungan } \\
\text { Interpersonal }\end{array}$ & Frekuensi & $\begin{array}{c}\text { Prosentase } \\
(\%)\end{array}$ \\
\hline Baik & 146 & 76,4 \\
\hline Sedang & 31 & 16,2 \\
\hline Kurang & 14 & 7,3 \\
\hline Total & 191 & 100.0 \\
\hline
\end{tabular}

Tabel 3 menunjukkan sebagian besar perawat memiliki hubungan interpersonal yang baik sebanyak 146 perawat $(76,4 \%)$.

Tabel 4 Gambaran Tingkat Stress Perawat

\begin{tabular}{ccc}
\hline Stres Kerja & Frekuensi & Prosentase (\%) \\
\hline Ringan & 72 & 37.7 \\
\hline Sedang & 70 & 36.6 \\
\hline Berat & 49 & 25.7 \\
\hline Total & 191 & 100 \\
\hline
\end{tabular}

Tabel 4 menunjukkan sebagian perawat memiliki tingkatan stress ringan sebanyak 72 perawat $(37,7 \%)$.

\section{Hasil Analisis Bivariat}

Tabel 5. Hasil Analisis Bivariat

\begin{tabular}{cc}
\hline Variabel & $\boldsymbol{p}$ value \\
\hline Masa Kerja & 0,001 \\
\hline Hubungan Interpersonal & 0,043 \\
\hline Beban Kerja & 0,030 \\
\hline
\end{tabular}

Berdasarkan tabel 5. diketahui bahwa hasil analisis didapatkan bahwa variabel masa kerja, hubungan interpesonal dan beban kerja seluruhnya memiliki nilai $p<0,05(\alpha=0,05)$, sehingga dapat disimpulkan bahwa variabel masa kerja, hubungan interpersonal dan beban kerja perawat berhubungan dengan stres kerja perawat.

\section{PEMBAHASAN}
1. Hubungan Masa Kerja dengan Stres Kerja Perawat

Hasil penelitian menunjukkan bahwa ada hubungan antara masa kerja dengan stres kerja perawat ( $\mathrm{p}$ value $=0,001)$. Munandar (2011) menjelaskan bahwa hubungan masa kerja dengan stres kerja berkaitan dengan rasa jenuh dalam bekerja. Pekerja dengan masa kerja lebih lama biasanya memiliki tingkat rasa jenuh terhadap pekerjaan lebih tinggi dibanding pekerja baru. Rasa jenuh tersebut bisa memicu stres di tempat kerja.

Hasil penelitian ini sejalan dengan penelitian yang dilakukan oleh Ibrahim (2016), Sahraian (2013), Ismafiaty (2011), Gobel (2014) yang mendapatkan hasil bahwa masa kerja baru dapat menjadi pemicu terjadinya stres kerja. Masa kerja baru terkait dengan kemampuan adaptasi terhadap lingkungan kerja, sedangkan masa kerja terlalu lama berkaitan dengan kejenuhan (Ismafiaty, 2011).

2. Hubungan Interpersonal dengan Stres Kerja Perawat

Hasil penelitian menunjukkan ada hubungan antara hubungan interpersonal dengan tingkat stres perawat ( $p$ value:0,043).

Liliweri (2015) menyatakan bahwa hubungan interpersonal yang kurang akibat adanya gangguan dalam interaksi sosial diantara pekerja, atasan, pasien atau keluarga pasien bisa memicu terjadinya stres pada perawat.

Hasil penelitian ini sejalan dengan Penelitian Laelasari (2016) yang menunjukkan bahwa tidak terjalinnya hubungan interpersonal yang baik memiliki potensi untuk mengalami stres kerja 9,4 kali lebih besa dibanding dengan adanya hubungan interpersonal yang baik. Kemudian penelitian Martha (2016) yang mendapatkan hasil bahwa kurangnya hubungan interpersonal bisa membuat stres kerja perawat meningkat.

3. Hubungan Beban Kerja dengan Tingkat Stres Perawat

Hasil peneliytian menunjukkan bahwa ada hubungan yang signifikan antara beban kerja dengan tingkat stres perawat ( $\mathrm{p}$ value: 0,030 ).

Gibson (2014) menyatakan bahwa beban kerja berlebih dan beban kerja terlalu sedikit merupakan pembangkit stres. Haryanti (2013) menjelaskan bahwa akibat dari jumlah tindakan yang tidak 
sebanding dengan jumlah tenaga perawat bisa memicu terjadinya stres kerja.

Hasil penelitian ini sejalan dengan penelitian Pratama (2014), Suratmi (2015), dan Nurmalasari (2012) yang menyatakan ada hubungan antara beban kerja dengan stres kerja.

\section{KESIMPULAN}

Berdasarkan hasil penelitian dapat disimpulkan bahwa Faktor-faktor yang berhubungan dengan stres kerja perawat adalah masa kerja (p:0,001), hubungan interpesonal (p:0,043) dan beban kerja (p:0,030).

\section{DAFTAR PUSTAKA}

\section{APA. (2012). Measures Organizational of http://supp.apa.org/books/ Preventive- Stress-Management- \\ Second/organizationalstressors.pdf. Depkes RI, 2014}

Donsu, Jenita DT. (2017). Psikologi Keperawatan.Yogyakarta : Pustaka Baru Press

Haryanti., Aini, Faridah., \& Purwaningsih, Puji. (2013). Hubungan Antara Beban Kerja dengan Stres Kerja Perawat di Instalasi Gawat Darurat RSUD Kabupaten Semarang. Jurnal Managemen Keperawatan, 1 (1).

Hawari, D. (2011). Manajemen Stres Cemas dan Depresi. Jakarta : Fakultas Kedokteran Universitas Indonesia.

Honey, Allfar End., dkk. (2012). Pengaruh Pelatihan Komunikasi Asertif pada Perawat Pelaksana yang Mengalami Konflik Interpersonal terhadap Kinerjanya dalam Memberikan Asuhan Keperawatan di Ruang Rawat Inap RSUD Solok. Ners Jurnal Keperawatan, 8 (2).

HSE. (2014). Stress at Work. http://www.acas.org.uk/media/pdf/q/c/St ress-at- work-advisory-booklet.pdf

Irza. (2016). Dasar-dasar Kesehatan dan Keselamatan Kerja. Jakarta: Kencana.Wahyuni (2012
Ismafiaty. (2011). Hubungan Antara Strategi Koping dan Karakteristik Perawat dengan Stres Kerja di Ruang Perawatan Intensif Rumah Sakit Dustira Cimahi. Jurnal Kesehatan Kartika.

Laelasari, Eva., Kurniawidjaja, L Meily. (2016). Faktor Kondisi Pekerjaan yang Mempengaruhi Stress Kerja pada Pegawai Negeri Sipil di Badan Litbang Kesehatan, Kementrian Kesehatan. Jurnal Ekologi Kesehatan, 15(2) : 127139.

Lai, J. Ma, S, Wang, Y, Cai, Z, Hu, J, Wei, N, $\mathrm{Wu}, \mathrm{J}, \mathrm{Du}, \mathrm{H}, \mathrm{Chen}, \mathrm{T}, \mathrm{Li}, \mathrm{R}, \mathrm{Tan}, \mathrm{H}$, Kang, L, Yao, L, Huang, M, Wang, H, Wang, G, Liu, Z, Hu, S (2020) „Factors Associated With Mental Health Outcomes Among Health Care Workers Exposed to Coronavirus Disease 2019"e, JAMA network open. doi: 10.1001/jamanetworkopen. 2020.3976

Liliweri, Alo. (2015). Prasangka \& Konflik : Komunikasi Lintas Budaya Masyarakat Multikultur.

Martha, Ainama Rizka Amalia. (2016). Beban Kerja Mental, Shift Kerja, Hubungan Interpersonal dan Stres Kerja pada Perawat Instalasi Intensif di RSD $d r$. Soebandi Jember. Jember : FKM Universitas Jember.

Munandar, Ashar Sunyoto. (2011). Psikologi Industri dan Organisasi. Jakarta : UI Press.

Pesant, G. (2016). Balancing Nursing Workload by Constrain Programming. Lecture Notes in Computer Science (including Subseries Lecture Notes in Artifical Intelligence and Lecture Notes in Bioinformatics), 9676 (Section 2). 294-302.

Waluyo, M. (2013). Manejemen Psikologi Industri. Jakarta: Indeks Permata Puri Media.

Widyasari, J.K. (2010). Hubungan antara Kelelahan Kerja dengan Stres Kerja pada Perawat di Rumah Sakit Islam Yarsis Surakarta. Fakultas Kedokteran : UNS. 
Adi Husada Nursing Journal, Vol. 7 No. 2, Desember 2021/ Hal. 61 https://doi.org/10.37036/ahnj.v7i1.201

Zhang, W., Wang, K., Zhao, W., \& Xue, Q.

100053(45),

$1-9$. (2020). Mental Health and Psychosocial https://doi.org/10.1159/000507639

Problems of Medical Health Workers during the COVID-19 Epidemic in China. Psychother Psychosom,

Zulfan Saam. (2012). Psikologi Keperawatan. Jakarta : PT. Raja Grafindo Persada. 